\title{
Contamination of the Aquatic Environment with Neonicotinoids and its Implication for Ecosystems
}

\author{
Francisco Sánchez-Bayo $^{1 *}$, Koichi Goka ${ }^{2}$ and Daisuke Hayasaka ${ }^{3}$ \\ ${ }^{1}$ Faculty of Agriculture and Environment, The University of Sydney, Eveleigh, NSW, Australia, ${ }^{2}$ National Institute for \\ Environmental Studies, Tsukuba, Japan, ${ }^{3}$ Faculty of Agriculture, Kindai University, Nara, Japan
}

\section{OPEN ACCESS}

Edited by:

Carsten A. Brühl,

University of Koblenz and Landau,

Germany

Reviewed by:

Alexa C. Alexander,

Environment Canada, Canada

Yong Liu,

Hunan Plant Protection Institute,

China

*Correspondence:

Francisco Sánchez-Bayo

sanchezbayo@mac.com;

francisco.sanchez-bayo@

sydney.edu.au

Specialty section:

This article was submitted to Agroecology and Land Use Systems,

a section of the journal

Frontiers in Environmental Science

Received: 15 August 2016

Accepted: 17 October 2016

Published: 02 November 2016

Citation:

Sánchez-Bayo F, Goka K and Hayasaka D (2016) Contamination of

the Aquatic Environment with

Neonicotinoids and its Implication for Ecosystems. Front. Environ. Sci. 4:71.

doi: 10.3389/fenvs.2016.00071
The widespread use of systemic neonicotinoid insecticides in agriculture results first in contamination of the soil of the treated crops, and secondly in the transfer of residues to the aquatic environment. The high toxicity of these insecticides to aquatic insects and other arthropods has been recognized, but there is little awareness of the impacts these chemicals have on aquatic environments and the ecosystem at large. Recent monitoring studies in several countries, however, have revealed a world-wide contamination of creeks, rivers and lakes with these insecticides, with residue levels in the low $\mu \mathrm{g} / \mathrm{L}$ (ppb) range. The current extent of aquatic contamination by neonicotinoids is reviewed first, and the findings contrasted with the known acute and chronic toxicity of neonicotinoids to various aquatic organisms. Impacts on populations and aquatic communities, mostly using mesocosms, are reviewed next to identify the communities most at risk from those that undergo little or no impact. Finally, the ecological links between aquatic and terrestrial organisms are considered. The consequences for terrestrial vertebrate species that depend mainly on this food source are discussed together with impacts on ecosystem function. Gaps in knowledge stem from difficulties in obtaining long-term experimental data that relates the effects on individual organisms to impacts on populations and ecosystems. The paper concludes with a summary of findings and the implications they have for the larger ecosystem.

Keywords: macroinvertebrates, ecological impacts, systemic insecticides, imidacloprid, meta-analysis, review

\section{INTRODUCTION}

Neonicotinoids are a novel class of chemical insecticides derived from the natural toxin nicotine. The first compound that was launched to the market in the early 1990s, imidacloprid, was hailed as the solution to the environmental problems caused by older insecticides such as organochlorines and organophosphates, e.g., spray drift onto non-target areas (Siebers et al., 2003), broad-spectrum toxicity to most organisms (Brown, 1978), fish kills (Fox and Matthiessen, 1982), bioaccumulation in fatty tissues (Matthiessen et al., 1982) and poisoning effects on the applicators (Cataño et al., 2008), among others.

Because they are systemic, neonicotinoids are typically applied to the roots of the crop plant, avoiding thus the need for spraying and contaminating nearby land by drift, although they can also be applied as foliar sprays (Elbert et al., 2008). In addition, the selectivity of neonicotinoids toward arthropods, and insects in particular, was an achievement only paralleled by the pyrethroids (derived from the natural toxin pyrethrum). However, unlike the latter insecticides, 
neonicotinoids are not toxic to either fish or zooplankton species, a great advantage for using them in environmental programs. Thirdly, their hydrophilic properties avoided any chance of bioaccumulation in organisms, and furthermore they were harmless to mammals (Tomizawa and Casida, 2005). These features provided safety to both environment and operators, mainly farmers, and became the key selling points in marketing (Jeschke and Nauen, 2008). Within a decade, imidacloprid was the top selling insecticide in the world, having displaced older chemistries (Jeschke et al., 2011). Newly developed neonicotinoids followed suit, to the point that they now constitute the largest group of insecticides in the global market (Simon-Delso et al., 2015).

Their marketing success, however, was tarnished by their association with honey bee failures in France (van der Sluijs et al., 2013). Many people now have become aware of the existence of neonicotinoids through reports in the media and the internet about bee declines. Hundreds of research papers have been written on this topic in recent years (Osborne, 2012), and the evidence suggests that neonicotinoids impacts on bees and other pollinators cannot be ignored (EFSA, 2013). Consequently, authorities have started to impose measures in Europe to reduce their use in crops that attract bees, like rapeseed (canola), sunflower, and maize (European Commission, 2013), and some countries (i.e., France and Germany) have recently banned the use of seeds treated with neonicotinoids (Garric and Hir, 2016).

As the debate about neonicotinoids has been focused on bees not many people are aware of their impacts on aquatic ecosystems. Yet they pose threats to this environment (SánchezBayo, 2014), more subtle perhaps but broader in scope when we analyse the consequences for the larger aquatic ecosystem.

This paper is a review of current knowledge about the toxicity of neonicotinoids to aquatic species, starting with their effects at the individual level, discussing their impacts on populations and aquatic communities, and concluding with the consequences that these impacts have on ecosystems. In addition, a meta-analysis of the contamination of freshwater systems with neonicotinoids to date adds a global perspective to the issues. There is urgency in assessing the advantages and disadvantages of the widespread use of this class of insecticides, so as not to repeat the mistakes of the past (Krebs et al., 1999).

\section{EFFECTS AT THE ORGANISMAL LEVEL}

The first neonicotinoid launched to the market, imidacloprid, had very low acute toxicity to the standard aquatic species used in regulatory testing of chemicals. The 48-h median lethal concentration (LC50) for the waterflea Daphnia magna was between 10 and $85 \mathrm{mg} / \mathrm{L}$ (ppm), which is several orders of magnitude higher than the LC50 of pyrethroids, organophosphorus and carbamate insecticides to the same species (Song et al., 1997; Tomlin, 2009). Similarly, the 96h LC50 for fish species were in the range $83-281 \mathrm{mg} / \mathrm{L}$ for rainbow trout (Oncorhynchus mykiss) and zebrafish (Danio rerio) (Ding et al., 2004; Tomlin, 2009). These data suggested that neonicotinoids would not have major impacts, if any, on aquatic ecosystems.
It was later found that other aquatic taxa were much more sensitive to imidacloprid than the standard test species. Thus, freshwater ostracods have 48-h LC50s in the range 185-719 $\mu \mathrm{g} / \mathrm{L}$ (ppb), which are 50-120 times lower than that of $D$. magna (Sánchez-Bayo and Goka, 2006b). Moreover, the LC50s for the amphipod Hyalella azteca are between 115 and $7 \mu \mathrm{g} / \mathrm{L}$ (ppb) depending on whether the exposure is for 2 or 28 days, and for midge larvae (Chironomus tentants) LC50s are in the range from 5 to $0.9 \mu \mathrm{g} / \mathrm{L}$ for the respective 4 and 28-day exposures (Stoughton et al., 2008). The latter values are four orders of magnitude lower than those for D. magna, indicating that somehow the initial toxicity assessment of this insecticide was flawed. Survival of midge larvae (Chironomus riparius) is also reduced in waters contaminated with mixtures of neonicotinoids (imidacloprid, thiacloprid) and pyrethroid insecticides (deltamethrin and esfenvalerate) (Kunce et al., 2015).

One particular aspect of neonicotinoids became apparent only after years of testing: median toxicity values varied significantly depending on the time of exposure. As mentioned above, the estimated LC50s for amphipods and midge larvae were one or two orders of magnitude lower for exposures of 28 days compared to standard exposures of 2 or 4 days. This translates in a large acute/chronic toxicity ratio, which for the mayfly Cloeon dipterum is 800 times when exposed for 28 days to imidacloprid (van den Brink et al., 2016). For the freshwater ostracod Cypridopsis vidua, the difference in LC50 between 2and 5-day exposures is three orders of magnitude! (SánchezBayo, 2009). This trend toward lower LC50s with increasing exposure time has been confirmed for several other species, including D. magna, Gammarus amphipods, black fly larvae, alderflies, mayfly and dragonfly nymphs (Beketov and Liess, 2008a; Roessink et al., 2013) when exposed to imidacloprid, thiamethoxam or thiacloprid (Figure 1). The consequence is an apparent "delayed mortality" (Beketov and Liess, 2008a), which can be observed in mesocosm trials that use a single pulse exposure: most of the organisms do not die immediately but start dying in large numbers after a week, and their populations disappear completely after a few weeks (Sánchez-Bayo and Goka, 2006a; Hayasaka et al., 2012a).

The physiological mechanism responsible for such unusual toxicological response is based on the agonistic mode of action of this class of chemicals, and was deduced by Tennekes (2010a) based on the model of Druckrey and Küpfmüller (1949). Neonicotinoids bind irreversibly to the nicotinic acetylcholine receptors ( $\mathrm{nAChR}$ ) embedded in the synaptic membranes of neurons, and their activation elicits a continuous electric impulse that eventually leads to the death of the neuron. The neuronal death toll accumulates as more and more chemical molecules bind to other nAChRs until the organism cannot cope with the damage and dies (Rondeau et al., 2014). Although an antagonistic mode of action on the same receptors has been reported for thiacloprid and thiamethoxam in Lymnaea stagnalis snails (Vehovszky et al., 2015), this inhibition of neurotransmission results in a similar outcome.

Aquatic organisms are constantly being exposed to residues of chemicals present in water, a medium from which they 


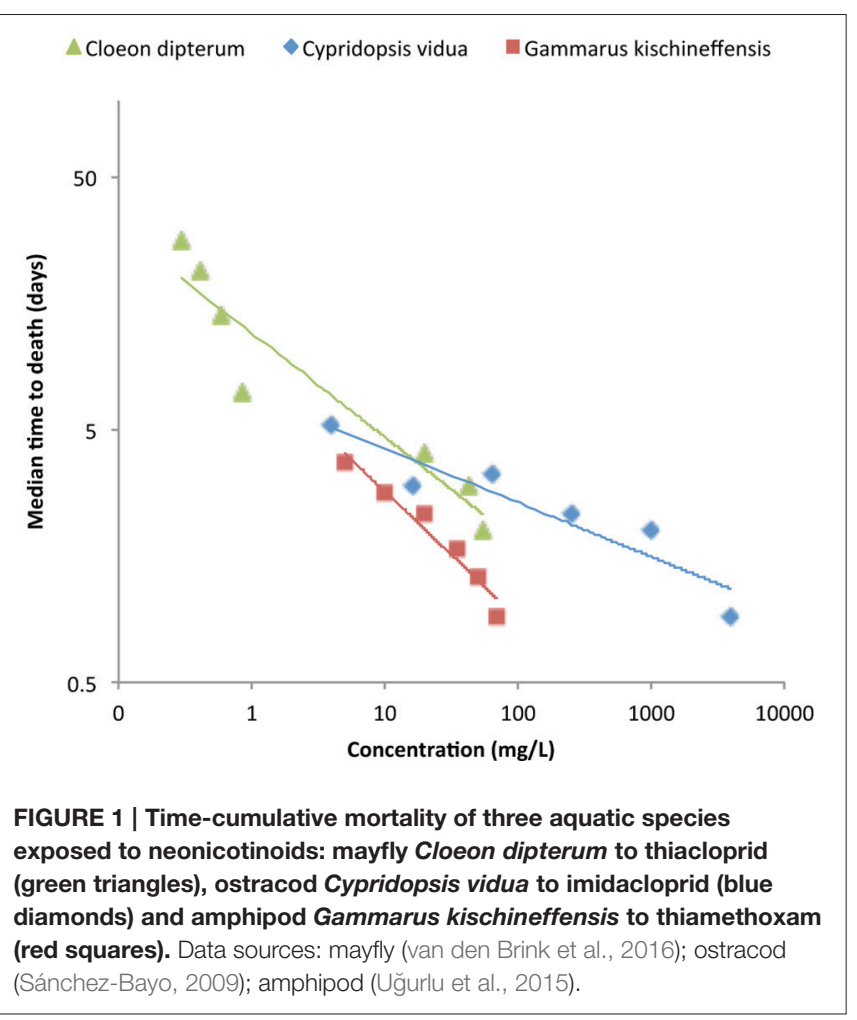

cannot escape. The time to reach the organism's death threshold depends on the internal concentration of insecticide, which in turn depends on its external concentration and the kinetics and detoxification ability of each species (Escher et al., 2011). The latter explains the enormous differences in susceptibility to this class of insecticides by various aquatic and terrestrial taxa, which range several orders of magnitude among insects and crustaceans alone (Morrissey et al., 2015).

The main difference between this mode of action and that of other pesticides is that effects are cumulative with time, because neurons do not regenerate. It has been termed time-cumulative toxicity (Tennekes and Sánchez-Bayo, 2013) to distinguish it from the more common toxicological response of insecticide inhibitors (e.g., organophosphorus, pyrethroids), which may bind irreversibly to specific receptors or enzymes but whose effects are temporary and can be reversed once the target receptors or enzymes are regenerated (Matsumura, 1985).

Aside from mortality, exposure to neonicotinoids causes a number of sublethal effects on aquatic organisms, such as feeding inhibition (Alexander et al., 2007; Kreutzweiser et al., 2007; Nyman et al., 2013), impaired movement (Motobayashi et al., 2012), reduced fecundity (Böttger et al., 2013), reduced body size in mayflies (Alexander et al., 2008) and fish (Hayasaka et al., 2012a) and immune-suppression in fish (Sánchez-Bayo and Goka, 2005). Downstream drift also occurs probably as an avoidance response to toxic conditions (Beketov and Liess, 2008b). All these effects were ignored for years, as the focus of neonicotinoid research was on bees, not on aquatic organisms. Obviously, some of these sublethal effects can be reversed if they do not rely directly upon the nervous system.

\section{IMPACTS AT THE POPULATION LEVEL}

Measurements of acute toxicity such as LC50s are useful to determine the potency of a chemical. Equally useful are the estimations of lowest effect concentrations (LOECs) based on observations of chronic exposure, although they are less accurate and reliable. What matters is to protect the populations of as many species as possible so as to maintain the integrity of the aquatic ecosystem services. To achieve that goal, it is imperative to know the range of sensitivities amongst species in different taxonomic groups, so that an evaluation of risks can be made. For aquatic species, toxicity data are scarce for all neonicotinoids except for imidacloprid and, to a lesser extent, thiacloprid. Therefore, assessments of risks and water quality thresholds for neonicotinoids are currently based on the acute toxicity of imidacloprid, mostly derived from short-term exposures of 2 or 4 days (Morrissey et al., 2015) and some chronic data (Smit et al., 2015).

The ECOTOX database of the US Environmental Protection Agency (EPA) provides LC50s of imidacloprid for 57 aquatic species belonging to several taxonomic groups (9 classes in 4 phyla). Sensitivities span six orders of magnitude, from the most susceptible mayflies (LC50 $\sim 1 \mathrm{ppb}$ ) to the most tolerant fish (LC50 $650 \mathrm{ppm}$ ) (Figure 2). It is apparent that the most susceptible species are aquatic insects, followed by crustaceans such as amphipods, ostracods and shrimps, then tubicifid worms and mussels. All cladoceran crustaceans (waterfleas) are very tolerant except perhaps Ceriodaphnia dubia, which is as sensitive as ostracods. Waterfleas are, therefore, not representative of other invertebrate taxa for imidacloprid nor any other neonicotinoid compound (Beketov and Liess, 2008a; Daam et al., 2013; Hayasaka et al., 2013).

Species sensitivity distributions (SSD, Figure 2) have been used by government agencies in some countries to derive water quality thresholds that protect their aquatic environment. In the Netherlands and other European countries the protective level for short-term peak concentrations of imidacloprid is 0.2 $\mu \mathrm{g} / \mathrm{L}$, whereas for long-term exposures the threshold is $8.3 \mathrm{ng} / \mathrm{L}$ (Smit et al., 2015). In the United States, the chronic invertebrate Aquatic Life Benchmark is $1.05 \mu \mathrm{g} / \mathrm{L}$, in Canada $0.23 \mu \mathrm{g} / \mathrm{L}$ (CCME, 2007; Anderson et al., 2015) and in Sweden $13 \mathrm{ng} / \mathrm{L}$ (Kreuger et al., 2010). Thresholds for other neonicotinoids are about the same order of magnitude in the US, but most countries have not established yet any regulation concerning neonicotinoids, while many still base their ecological assessments on the misleading toxicity data for Daphnia and fish.

The above regulatory thresholds are only a guide. Unlike with previous pesticides, protective levels for neonicotinoids cannot be achieved by setting a concentration benchmark because, as already explained, the effects of neonicotinoids increase with exposure time. An alternative is to assess the impact on populations using the predicted affected fraction (PAF) of species, which is determined by comparing waterborne residue levels from monitoring surveys with the SSD. Data on water residues for these compounds have been gathered in the past decade; prior to 2005 only a few surveys found some imidacloprid in a watershed and two streams of New York State (USGS, 2002; 


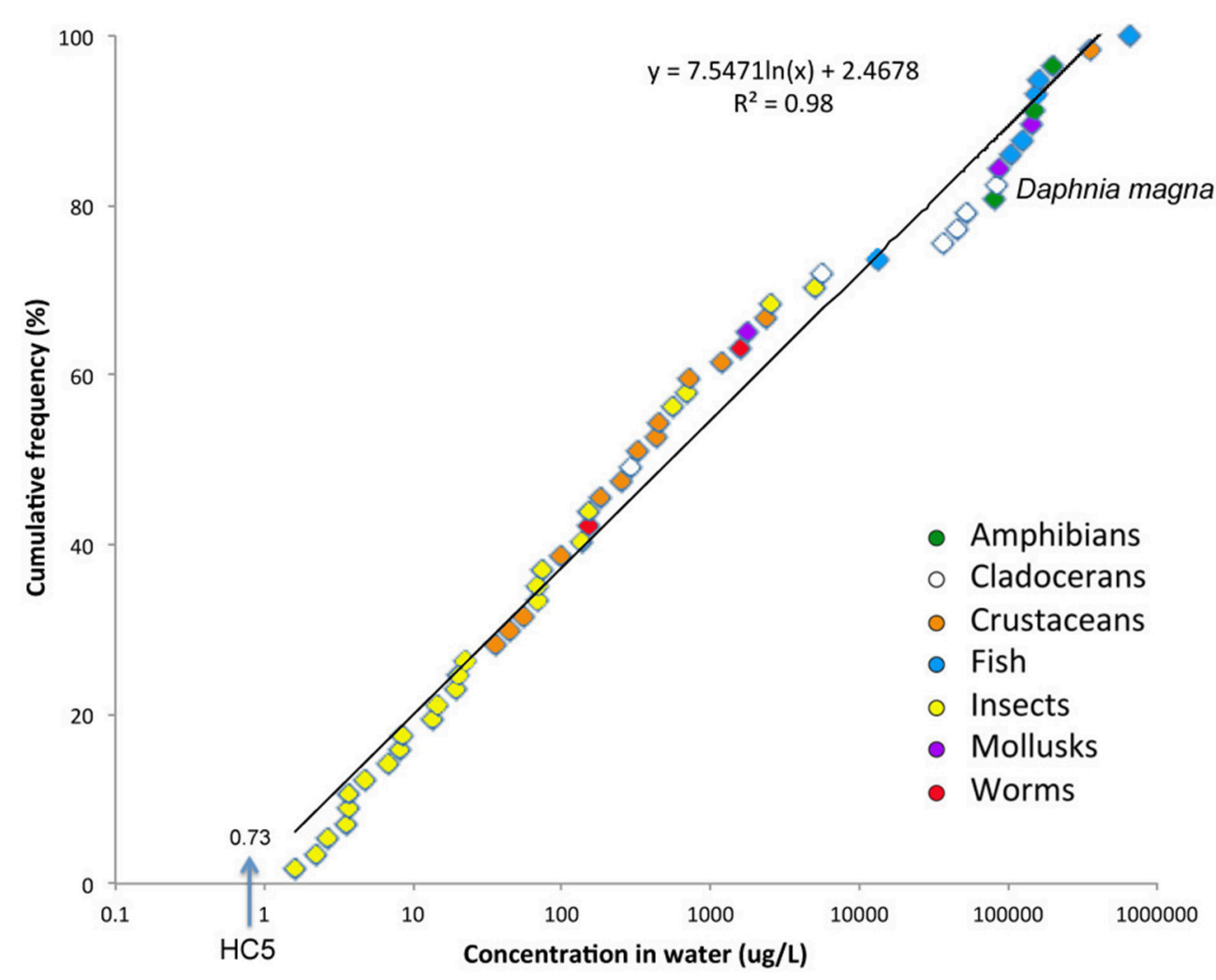

FIGURE 2 | Species sensitivity distribution (SSD) for acute toxicity of imidacloprid (LC50) to aquatic organisms. The hazard concentration affecting 5\% of species (HC5, $\mu \mathrm{g} / \mathrm{L})$ is indicated. Source: ECOTOX database https://cfpub.epa.gov/ecotoX/.

Phillips and Bode, 2004) and in drains from potato fields in Canada (Denning et al., 2004; CCME, 2007). A meta-analysis of all residue data from 11 countries available to date (Table S1) revealed the following:

(i) up to six neonicotinoids are currently present in water bodies all over the world. Average concentrations were similar for all compounds, ranging from $0.08 \mu \mathrm{g} / \mathrm{L}$ (dinotefuran) to $0.73 \mu \mathrm{g} / \mathrm{L}$ (imidacloprid); the highest concentrations detected so far were for imidacloprid and thiamethoxam (320 and $225 \mu \mathrm{g} / \mathrm{L}$, respectively) (Figure 3).

(ii) average residue levels have increased over the past 15 years, with highest rates of increase for clothianidin and thiamethoxam reflecting the worldwide trend in usage of these two compounds (Simon-Delso et al., 2015; Figure 4A).

(iii) the frequency of detection varies widely from country to country, with $100 \%$ detections for some compounds in several regions. On average neonicotinoid detections were found in $13 \%$ (acetamiprid) to $57 \%$ (dinotefuran) of all waters, and they also showed an increasing trend with time; again, the highest increases were for clothianidin and thiamethoxam (Figure 4B).

Contrasting these data with the protective levels established in some countries, the average concentration of all neonicotinoids in water exceeded the European guidelines $27 \%$ of the time, and the Canadian and United States guidelines 66 and $79 \%$ of the time, respectively, whereas maximum concentrations can exceed the European guidelines 35\% of the time (Morrissey et al., 2015).

These findings are of concern. The increasing trend in detections is obviously due to two factors: (i) a major effort in looking for these compounds in recent times, which contrasts with the absence of data in previous years; and (ii) better analytical capabilities, with current limits of detection around $1 \mathrm{ng} / \mathrm{L}$ or less using either HPLC (Sánchez-Bayo and Hyne, 2014) or LC-MS/MS instrumentation (Hladik and Calhoun, 2012; Yamamoto et al., 2012). However, the increasing residue levels are of great concern, as they indicate that residues in soil, where most of these insecticides are applied, are accumulating over the years. Indeed, there is evidence that such accumulation is happening in countries with a long history of using seeds treated with imidacloprid (Jones et al., 2014; Douglas and Tooker, 2015), although residues of thiamethoxam or clothianidin may plateau if crop rotation is used over a few years (Schaafsma et al., 2016). This accumulation results primarily from the fact that $80-90 \%$ of the insecticide in the coated-seeds and granules remains in the soil at the end of the cropping season (Sur and Stork, 2003; Goulson, 2013), and dissipation from soil is slower than in water: half-lives of neonicotinoids in soil are between 50 and 600 days for the four most commonly used compounds (Bonmatin et al., 2015), whereas photolytic hydrolysis in water can dissipate waterborne residues in a few 


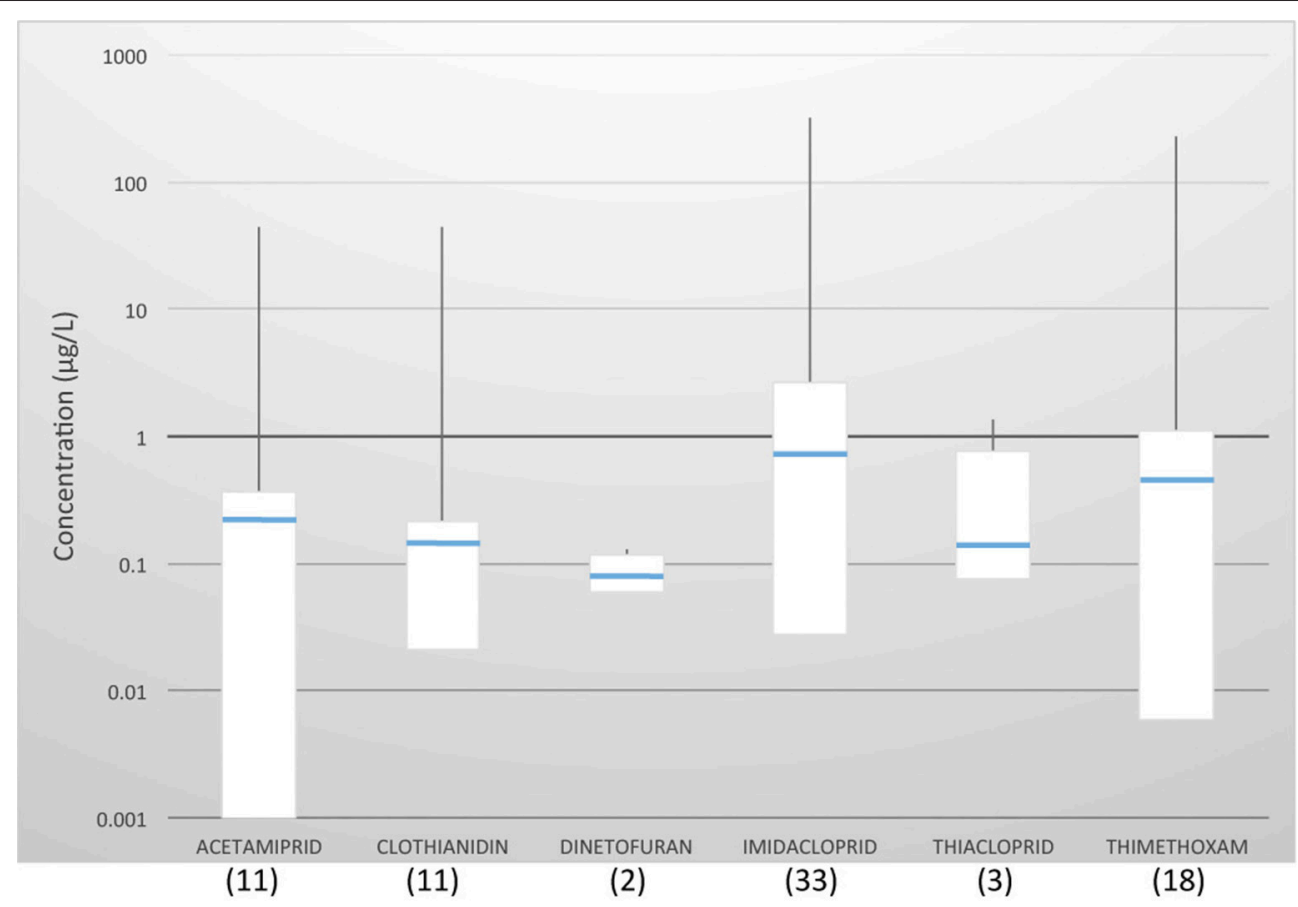

FIGURE 3 | Worldwide survey of neonicotinoid residues in water. The number of surveys reporting each chemical is in brackets. Boxes contain the residues between the first and third quartile; blue lines indicate the geometric mean; vertical lines show the outliers. Sources: see Table S1.

days (Phong et al., 2009; Thuyet et al., 2011). Degradation in sediments is faster for newly developed compounds like cycloxaprid (Liu et al., 2015). Up to $6 \%$ of imidacloprid residues in soil can be transported in runoff after storm events (Thuyet et al., 2012), but most of the residual chemical would remain in the applied field, from where it moves readily into ground waters, particularly thiamethoxam, imidacloprid, clothianidin (González-Pradas et al., 2002; Miranda et al., 2011; Bajeer et al., 2012) and dinotefuran (Kurwadkar et al., 2014). The increasing use of products containing neonicotinoids and their repeated application as coated seeds in agricultural fields (Douglas and Tooker, 2015) adds every year a new layer of residues to the soil, and hence to the waters, where residue levels are a reflection of those present in soil at any time (Hladik et al., 2014; Schaafsma et al., 2015).

By comparing the distribution of waterborne residues of imidacloprid to its SSD, estimations of the PAF are made to assess its current impact on aquatic organisms, i.e., the loss of half the populations exposed (Figure 5). Surveys to date indicate that up to $40 \%$ of species are being seriously affected in streams of Maryland, where average residue levels are $5.4 \mu \mathrm{g} / \mathrm{L}$ and can reach $131 \mu \mathrm{g} / \mathrm{L}$ (Johnson and Pettis, 2014), and a similar proportion in draining ditches from greenhouses in Sweden (average $3.2 \mu \mathrm{g} / \mathrm{L}$ and highest $89 \mu \mathrm{g} / \mathrm{L}$ ) (Kreuger et al., 2010). In three agricultural valleys of California, imidacloprid is currently affecting up to $11 \%$ of aquatic species (Starner and Goh, 2012), and in the Sydney basin up to $14 \%$ of species are being affected in streams that receive water from turf farms (Sánchez-Bayo and Hyne, 2014). Only streams and estuaries contaminated mostly with urban runoff, e.g., San Francisco (Weston et al., 2015), have minimal number of species affected. One can expect similar impacts for the other neonicotinoid residues, although it is not possible to assess them at this stage so long as the data available are insufficient.

This preliminary assessment is only based on the acute toxicity data (Figure 2) as determined in laboratories. For more realistic assessments of the long-term impacts, field and mesocosm studies are required, as explained in the next section.

\section{IMPACTS ON AQUATIC COMMUNITIES}

Some 22 studies on the impacts of neonicotinoids on aquatic communities have been conducted to date. Most of them comprise mesocosms that used imidacloprid, with five studies using thiacloprid and one acetamiprid in addition to those two compounds (Table S2). These studies were carried out in Japan (rice mesocoms), Portugal (field trials), Canada, and Germany (streams and microcosms). The most striking feature of these studies is their consistency in reporting population and community effects at levels well below the LC50s of the aquatic species tested. This is unusual, since field or mesocosms studies under realistic scenarios typically report fewer impacts of pesticides and other toxicants than in closed laboratory conditions (Cleveland et al., 2002). Reduced exposures, due mainly to chemical losses by microbial degradation, hydrolysis and other environmental factors, are usually responsible for the lesser impacts under field conditions (Maund et al., 1997). 


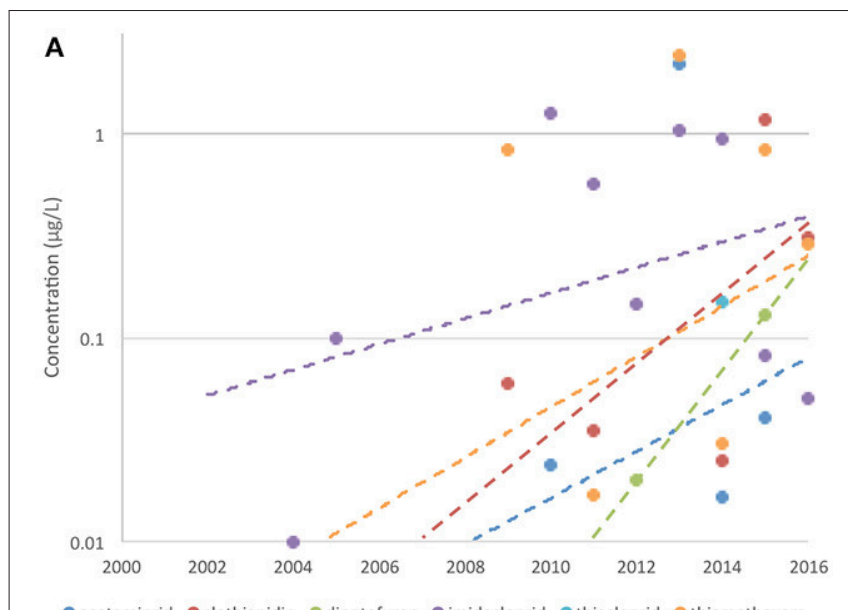

- acetamiprid •clothianidin @ dinotefuran $\bullet$ imidacloprid $\bullet$ thiacloprid $\bullet$ thiamethoxam

B

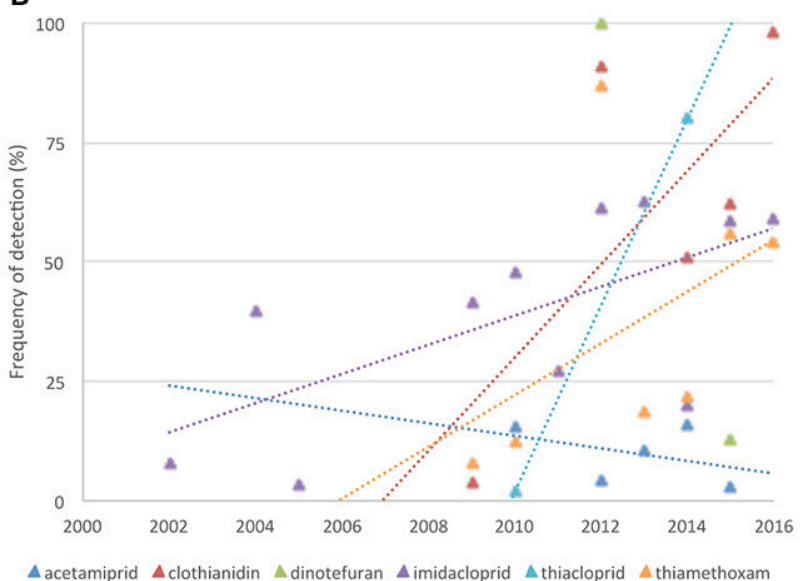

FIGURE 4 | Temporal trends of (A) concentrations of neonicotinoids in waters of the world, and (B) their frequency of detection. Sources: see Table S1.

A reduced abundance in aquatic insects is apparent when concentrations of imidacloprid in water are above 1 or $2 \mu \mathrm{g} / \mathrm{L}$ (Sánchez-Bayo and Goka, 2006a; Pestana et al., 2009; Hayasaka et al., 2012a; Colombo et al., 2013). Population reductions in the short-term are caused by direct toxicity, but in mesocosms such reductions affect the structure of the macroinvertebrate communities when residues are one or two orders of magnitude lower than the LC50s for most species, as more tolerant taxa tend to increase in numbers to fill the niche vacuum thus created in the ecosystem. Some of these changes are predictable. For instance, waterfleas increased in numbers when grazers such as ostracods were eliminated in rice mesocosms treated with imidacloprid (Sánchez-Bayo et al., 2007), whereas the disappearance of chironomid larvae brought about increases in Radix sp. snails (Colombo et al., 2013). In other cases, opportunistic predators (e.g., Heteroptera, Coleoptera, Odonata) and scavengers (e.g., Amphipoda) that feed on the moribund insects or their corpses have a temporary increase in food availability (Sánchez-Bayo and Goka, 2006a). Interestingly, the negative impacts on predatory copepod populations in rice fields are followed by upsurges of mosquitoes but not of chironomids. Consequently, the overall biodiversity of the aquatic communities is negatively affected (Pestana et al., 2009). Similar impacts are observed in mesocosms treated with thiacloprid at $3.2 \mu \mathrm{g} / \mathrm{L}$ or above (Kattwinkel et al., 2016). This is not surprising, as the HC5 for thiacloprid derived from outdoor stream mesocosms is $0.72 \mu \mathrm{g} / \mathrm{L}$ (Beketov et al., 2008), the same as that calculated for imidacloprid (HC5 $=0.73$ $\mu \mathrm{g} / \mathrm{L}$, Figure 2).

Treatments of rice mesocosms with imidacloprid at different rates over 4 years in Japan resulted in community impacts that were related to the initial concentrations of this insecticide in water, from 240 to $40 \mu \mathrm{g} / \mathrm{L}$. Average reductions of $46-62 \%$ were recorded among the plankton, neuston, nekton or benthos communities (Figure 6A), but the specific taxa groups and species affected differed from 1 year to another (Sánchez-Bayo et al., 2007; Hayasaka et al., 2012b). The greatest impacts (>45\% reductions) occurred in ostracods, mayflies and snails, followed by chironomids, dragonflies, damselflies and some Hemiptera predators such as Corixidae, Mesoveliidae and Anthocoris sp. Emergence of dragonflies is also reduced by more than $80 \%$ (Jinguji et al., 2013). By contrast, waterfleas increased by $75 \%$ and Diptera larvae (excluding chironomids) by $15 \%$. A similar trial in a rice field in Portugal measured initial concentrations of $52 \mu \mathrm{g} / \mathrm{L}$ imidacloprid in water, and average weighted concentrations of $8 \mu \mathrm{g} / \mathrm{L}$, which were estimated to affect $40-63 \%$ of the aquatic species (Daam et al., 2013). These observations are consistent with the impacts in Canadian stream mesocosms (Figure 6B), where weekly imidacloprid pulses at 2 or $20 \mu \mathrm{g} / \mathrm{L}$ had the highest reductions on worms (75\%), caddisflies (70\%), mayflies and stoneflies (both 68\%) (Pestana et al., 2009).

Moreover, many of these populations are decimated and their recovery is either slow or, if there is competition with other species, it does not take place (Liess et al., 2013). Recovery of most populations only occurs when the neonicotinoid concentrations in water or sediment are below $1 \mu \mathrm{g} / \mathrm{L}$ (Hayasaka et al., 2012b), whereas many univoltine or semivoltine species do not recover at all. Nor does the structure of the communities revert to the original situation, because some species disappear while others take over and increase in numbers (Beketov et al., 2008; Hayasaka et al., 2012a). These impacts contrast with those caused by other pesticides, which tend to produce a large initial mortality upon target and non-target populations alike but allow the recovery of the species affected within a few weeks (van den Brink et al., 1996; Brock et al., 2010). Thus, aquatic communities of rice paddies recovered completely in a week after foliar application of the insecticide etofenprox took place (Sánchez-Bayo et al., 2007). The reason for this difference lies in the delayed mortality after chronic exposure to very low concentrations of neonicotinoids in water or sediments and, for more tolerant species like Gammarus roeseli, in their reduced fecundity under similar conditions (Böttger et al., 2013). By contrast, many pyrethroids and organophosphates (with the exception of persistent compounds like chlorpyrifos) do not produce time-cumulative mortality (Parsons and Surgeoner, 1991) since their exposure is limited in time (Lahr et al., 2000; Medina et al., 2004).

Apart from the lethal effects on communities, blackfly larvae (Simulium latigonium), mayfly nymphs (Baetis rhodani) 


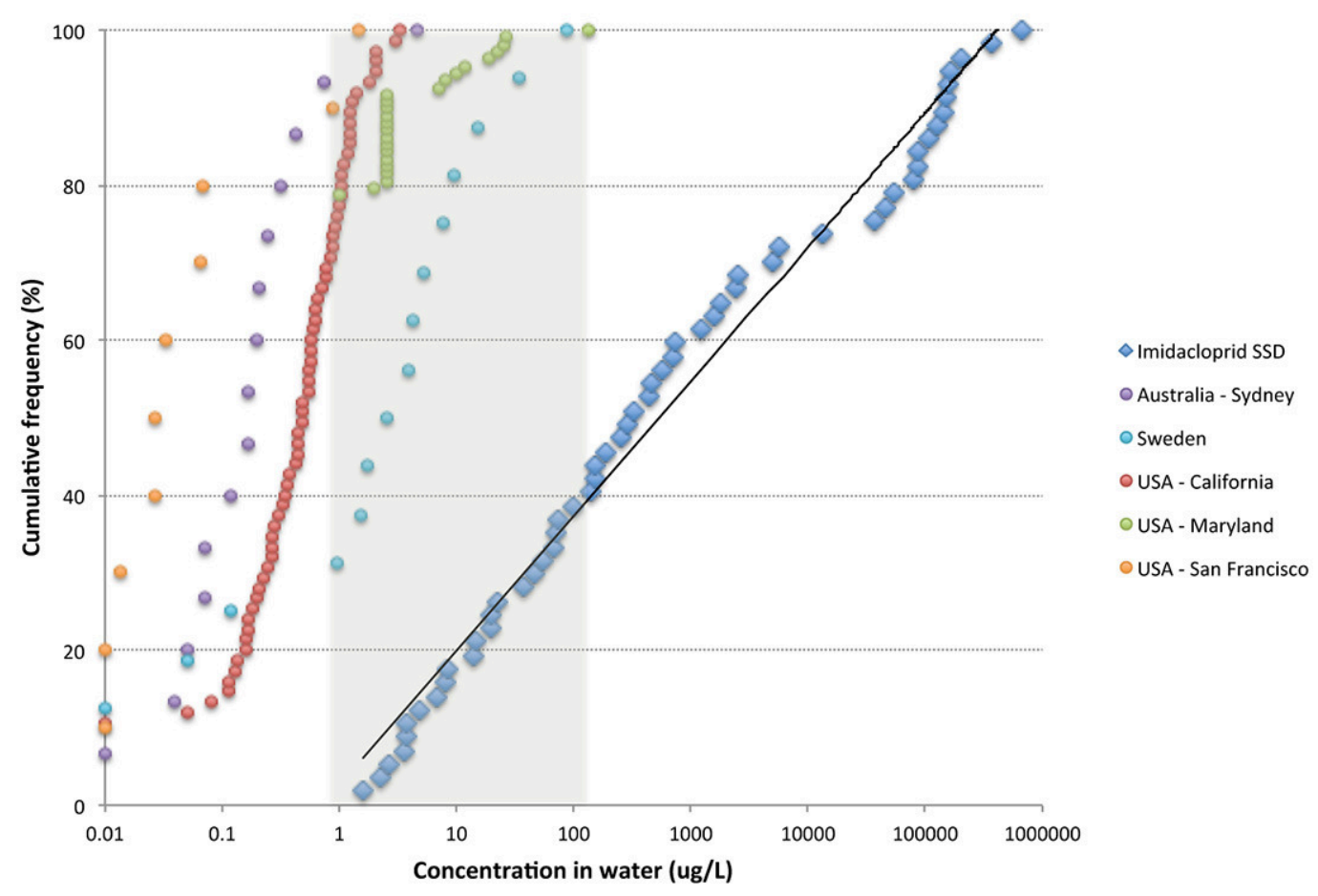

FIGURE 5 | Distribution of waterborne residues of imidacloprid in several countries contrasted with the acute SSD for this compound. Data sources: Australia (Sánchez-Bayo and Hyne, 2014); Sweden (Kreuger et al., 2010); USA California (Starner and Goh, 2012); USA Maryland (Johnson and Pettis, 2014); USA San Francisco (Weston et al., 2015).

and amphipods (Gammarus pulex) drift downstream when concentrations of various neonicotinoids in water are lower than $1 / 10$ of the species LC50 (Beketov and Liess, 2008b), indicating that these organisms respond to the adverse effects of these neurotoxicants at sublethal levels, i.e., below $0.37,0.46$, and 27 $\mu \mathrm{g} / \mathrm{L}$ of either thiacloprid, acetamiprid or imidacloprid for the respective species above.

Finally, when mayfly nymphs (Baetis rhodani) and Gammarus fossarum are exposed together to sublethal levels of thiacloprid, the amphipod increases its predation on the nymphs but reduces its shredding of litter at concentrations as low as $0.5-1$ $\mu \mathrm{g} / \mathrm{L}$ (Englert et al., 2012). Imidacloprid also reduces the litter decomposition carried out by stoneflies (Pteronarcys dorsata) and crane flies (Tipula sp.) at concentrations below $12 \mu \mathrm{g} / \mathrm{L}$ (Kreutzweiser et al., 2008b), probably due to a feeding inhibition effect of this insecticide, which has also been observed with other detritivores such as Gammarus pulex (Nyman et al., 2013) and Eisenia fetida earthworms (Kreutzweiser et al., 2008a). The implications of these impacts for the larger ecosystem are discussed next.

\section{IMPACTS ON THE ECOSYSTEM}

The consequences of all the above for the larger ecosystem have not been studied in detail yet. Difficulties in obtaining longterm experimental data that relates the effects on individual organisms to impacts on ecosystems prevent carrying out such studies. However, it is clear that some predictions can be made from the limited set of observations about the effects on aquatic communities reported so far. At least two main areas of concern can be identified: reduced capacity for decomposition of organic debris by aquatic organisms and starvation of insectivores and other vertebrate fauna that depend on invertebrates as a major or only food source (Figure 7).

\section{Reduced Decomposition Capacity}

The recycling of organic matter that falls into water bodies is an essential ecosystem function that not only provides food for a wide range of aquatic and benthic organisms but also ensures the water quality is adequate for all other organisms that use it, including ourselves.

It is well established that mayfly (Ephemeroptera), caddisfly (Trichoptera), and stonefly (Plecoptera) nymphs are the most sensitive aquatic organisms to most pollutants, so they are considered bioindicators of water quality (Morse et al., 1993; von der Ohe et al., 2007). They are shredders of leaves and other debris found at the bottom of creeks and streams that run through forested and agricultural areas, although not the only ones: larvae of crane flies (Tipulidae), black flies (Simulidae) and other Diptera taxa perform the same function, together with amphipods, ostracods and aquatic isopods. The fact that litter decomposition by stoneflies, crane flies, mayflies and amphipods is significantly reduced by concentrations of neonicotinoids that are currently found in many aquatic environments is of 


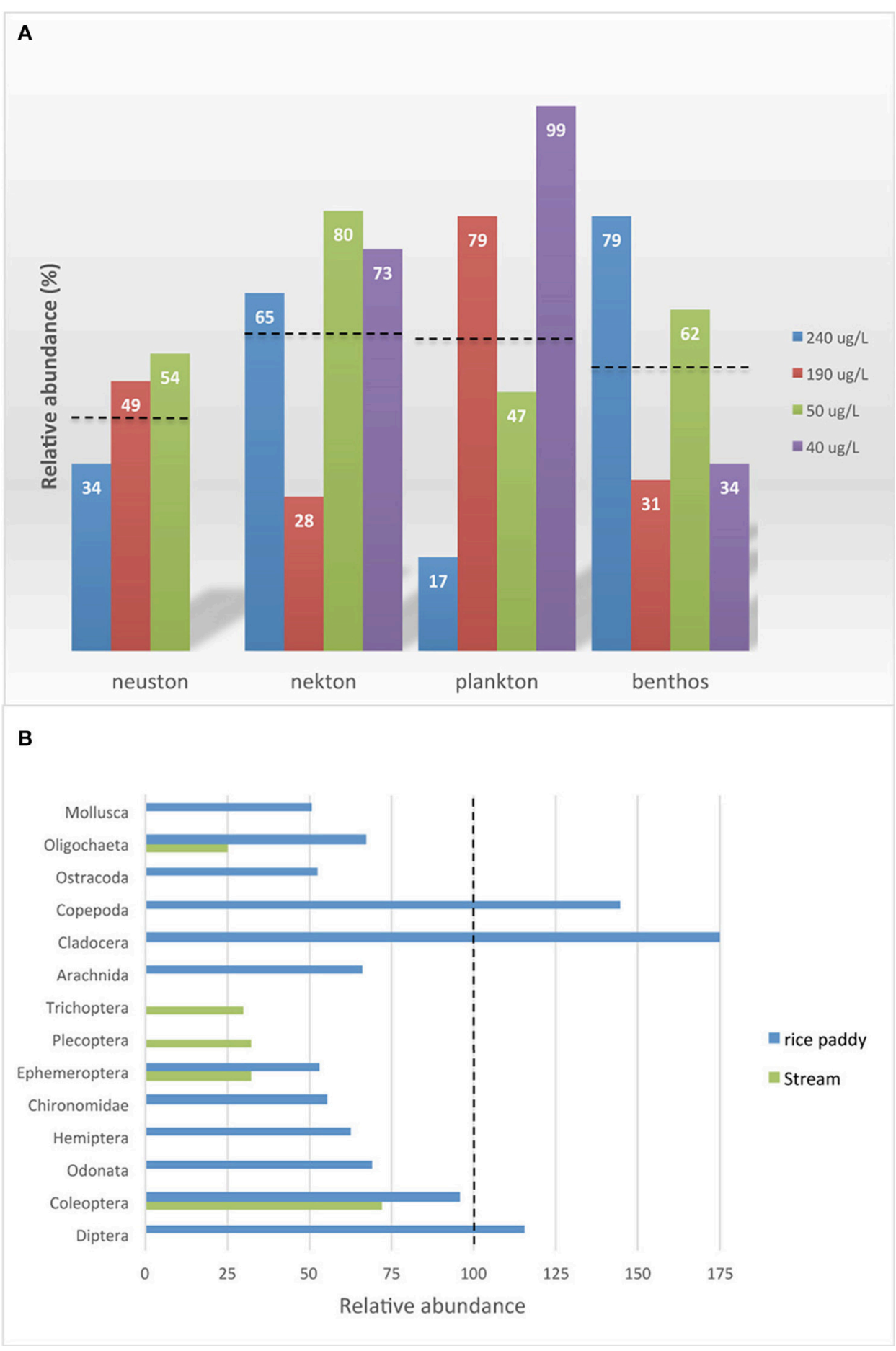

FIGURE 6 | Relative abundance with respect to controls of aquatic invertebrates in imidacloprid-treated mesocosms. (A) Communities in rice paddies for different initial concentrations of imidacloprid; dashed lines indicate average reductions. (B) Invertebrate taxa in rice paddies and streams; vertical dashed line indicates the control. Data sources: rice paddies (Sánchez-Bayo and Goka, 2006a; Sánchez-Bayo et al., 2007; Hayasaka et al., 2012a,b); streams (Pestana et al., 2009).

concern (Kreutzweiser et al., 2007). Even if some individuals may survive in depleted populations, they still will be unable to carry out the decomposition function properly due to the feeding inhibition caused by these neurotoxicants, which will render those individuals unfit to do their job. Naturally, insufficient feeding leads to reduced ability for reproduction (Böttger et al., 2013), so the long term prospects are poor for the detritivore populations affected. 


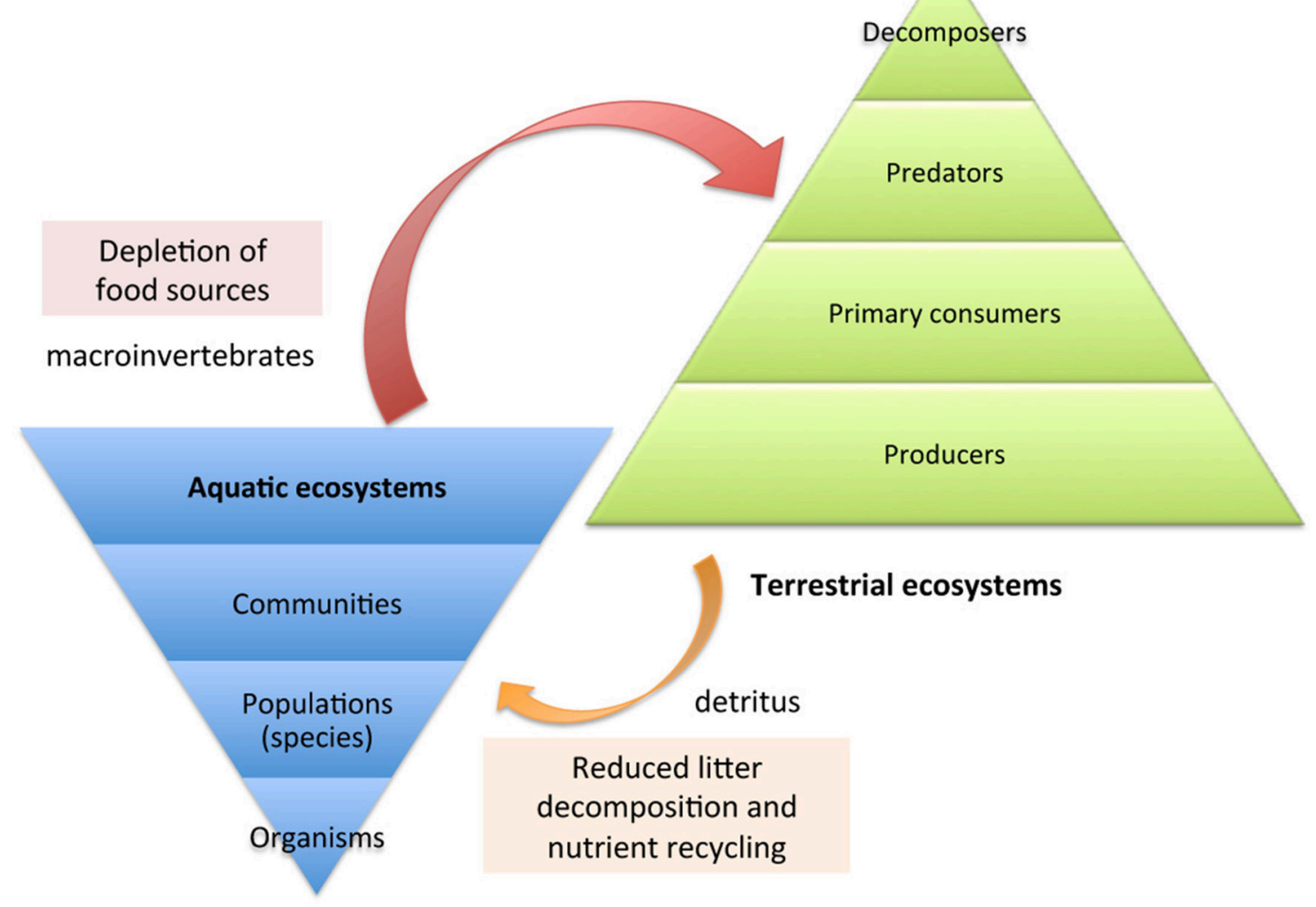

FIGURE 7 | Ecosystem impacts of water-borne neonicotinoid residues.

To many regulators of chemicals, whether mayflies or other macroinvertebrates are depleted is not important, or at least not as much as the increase in productivity that farmers may obtain from using products like neonicotinoids, although the latter benefits are questionable-see (Seagraves and Lundgren, 2012; Macfadyen et al., 2014). Just because macroinvertebrates are not seen, since they are small and live at the bottom of ponds and streams, this does not mean they can be dispensed with. As Suter and Cormier have argued, these small creatures are present in ecosystems for an important reason (Suter and Cormier, 2015).

Given that more than half of the waters are contaminated (Figure 4) with neonicotinoid levels that impair this important ecosystem function, higher organic and inorganic pollution can be expected wherever these insecticides are present. Microbial degradation of the debris may still occur, but it would be slower and produce undesirable by-products such as methane and sulfides (Sorrell and Boon, 1992; Kwok et al., 2005). The combined impacts by neonicotinoids and other pollutants could gradually poison the surface waters in many parts of the world.

\section{Starvation of Insectivores and Invertebrate Feeders}

Indirect impacts are a common feature of many pesticides, one that has no relation to the toxicity on the species ultimately affected (Sánchez-Bayo, 2011). Thus, neonicotinoids do not cause fish mortality directly, but because aquatic invertebrates are a rich food source for many species of fish, depletion and disappearance of this source in waters contaminated with neonicotinoids could affect fish stocks in freshwater ecosystems. In the Netherlands, where residues of imidacloprid in water are the highest in the world (Table S1), correlations between such residues and the decline of arthropod taxa such as Ephemeroptera, Odonata, Diptera and some crustaceans have been found (van Dijk et al., 2013). Although not all the declines can be blamed on neonicotinoids, because other pesticide residues are also found and can have similar impacts (Beketov et al., 2013; Vijver and van den Brink, 2014), it would seem that neonicotinoids are clearly involved.

As already mentioned, populations of aquatic species exposed to neonicotinoids often do not recover. Indeed, the overall abundance of macroinvertebrates in mesocosms treated with imidacloprid or thiacloprid was lower than that in the controls after a few months, while some species disappeared completely (Sánchez-Bayo and Goka, 2006a; Beketov et al., 2008). This suggests that recovery of the extinct populations in the following year must require re-colonization from nearby areas. The elimination of predatory species results in the increase of prey species, with some of them, like mosquitoes (Figure 6B), being a nuisance and a health hazard. In agricultural areas treated extensively with seeds containing neonicotinoids the chances 
of re-colonization are less frequent for species that are not very mobile. Aquatic insects and invertebrate species are being removed from many land and water areas and heading toward extinction. This dire prediction is not far from the reality in some places. An entomological survey carried out in a region of Germany comprising agricultural land and a nature reserve reported a decline of $75 \%$ in flying insect abundance between 1989 and 2013 (Sorg et al., 2013). Many of these flying insects have aquatic life cycles, and their disappearance is probably due to their larvae not having survived in water. This astonishing reduction in entomofauna parallels the decline of wild bee species in North America and the British Isles (Fitzpatrick et al., 2007; Cameron et al., 2011; Woodcock et al., 2016) and butterflies in California and England (Gilburn et al., 2015; Forister et al., 2016) in the same period. It must be remembered that neonicotinoids were introduced in the early 1990s.

Riverine ecosystems are notorious for the rich biodiversity they encompass (Sánchez-Bayo, 1991). Many of the vertebrates living around rivers, lakes and ponds are insectivorous species that depend almost exclusively on aquatic invertebrates as their food source: frogs, newts, skinks and lizards, a large array of birds including passerines and waders, bats and shrews. All these animals, whether terrestrial or amphibian, draw their food from flying insects, their aquatic larvae, crustaceans and worms that live in the water environment. Consequently, the depletion of this food source must necessarily affect them (Tennekes, 2010b). To date, the only study available that makes a connection between bird declines and neonicotinoids in water was carried out in the Netherlands (Hallmann et al., 2014). The authors of that study collected information on 15 species of passerine birds in that country over 20 years since 1993, and correlated their abundance with residue concentrations of imidacloprid and other pesticide residues in water during the same period. All bird species studied were either insectivorous or fed insects and larvae to their offspring during the breeding season. The only pesticide that explained the declining trends of 14 bird species was imidacloprid, whereas other factors that were taken into consideration, such as urban or agricultural area, availability of some cereal crops, fertilizer use and others, were discarded by the statistical analysis. For the 6 species that showed a significant decline with imidacloprid residues, the average bird population decline was $3.5 \%$ per year in areas with residue levels above $20 \mathrm{ng} / \mathrm{L}$ (ppt). These levels are below the HC5 for imidacloprid $(0.73 \mu \mathrm{g} / \mathrm{L}$, Figure 2) and well below the LC50s of all aquatic insects tested. However, as demonstrated in the microcosm and mesocosm studies, they are sufficient to cause sublethal effects and delayed mortality, all of which can eliminate entire populations of invertebrates, without recovery in many cases.

Starvation by depletion of food sources due to pesticides was demonstrated for gray partridges (Perdix perdix) in England (Potts, 1986). Also, applications of fipronil insecticide for locust control in Madagascar reduced the abundance of two species of tenrec, a skink and iguanian lizards that depended on termites as their main food source (Peveling et al., 2003). Evidence of similar impacts by neonicotinoids on vertebrate taxa other than birds does not exist because of difficulties in obtaining relevant long-term experimental data. However, if terrestrial birds, lizards and mammals can be taken as examples of what occurs in nature when pesticides reduce the food source, it is reasonable to think that other taxa that are experiencing worldwide declines, such as frogs and bats can be affected by indirect neonicotinoid impacts on the aquatic environment (Mason et al., 2013). Establishing the link between food depletion and population declines in some species is not difficult, but linking food depletion to individual chemical causes is a more challenging task.

\section{CONCLUSION}

Negative impacts of neonicotinoids in aquatic environments are a reality. Initial assessments that considered these insecticides harmless to aquatic organisms may have led to a relaxation of monitoring efforts, resulting in the worldwide contamination of many aquatic ecosystems with neonicotinoids.

The decline of many populations of invertebrates, due mostly to the widespread presence of waterborne residues and the extreme chronic toxicity of neonicotinoids, is affecting the structure and function of aquatic ecosystems. Consequently, vertebrates that depend on insects and other aquatic invertebrates as their sole or main food resource are being affected. Declines of insectivore bird species are quite evident so far, but many other terrestrial and amphibian species may be at risk.

Solutions must be found soon if we are to save the biodiversity not only of aquatic ecosystems, but all other ecosystems linked by the food web. Since the prophylactic use of seeds treated with neonicotinoids is responsible for most of the soil and aquatic contamination, while there is evidence of little productivity gain, one obvious solution is to stop the marketing of seeds coated with these insecticides (van der Sluijs et al., 2015) and use alternative and carefully targeted methods for pest control in agriculture (Douglas and Tooker, 2015; Furlan and Kreutzweiser, 2015), such as integrated pest management (IPM). At the same time, remediation systems based on photolytic processes (Malato et al., 2001) and wetlands phyto-remediation (Beketov and Liess, 2008c) should be implemented to reduce as much as possible the current contamination by these and other pollutants.

\section{AUTHOR CONTRIBUTIONS}

FS wrote the first draft and KG and DH added and corrected the original version. All three authors contributed equally to the experimental data reviewed here.

\section{SUPPLEMENTARY MATERIAL}

The Supplementary Material for this article can be found online at: http://journal.frontiersin.org/article/10.3389/fenvs. 2016.00071/full\#supplementary-material 


\section{REFERENCES}

Alexander, A. C., Culp, J. M., Liber, K., and Cessna, A. J. (2007). Effects of insecticide exposure on feeding inhibition in mayflies and oligochaetes. Environ. Toxicol. Chem. 26, 1726-1732. doi: 10.1897/07-015R.1

Alexander, A. C., Heard, K. S., and Culp, J. M. (2008). Emergent body size of mayfly survivors. Freshw. Biol. 53, 171-180. doi: 10.1111/j.1365-2427.2007.01880.x

Anderson, J. C., Dubetz, C., and Palace, V. P. (2015). Neonicotinoids in the Canadian aquatic environment: a literature review on current use products with a focus on fate, exposure, and biological effects. Sci. Total Environ. 505, 409-422. doi: 10.1016/j.scitotenv.2014.09.090

Bajeer, M. A., Nizamani, S. M., Sherazi, S. T. H., and Bhanger, M. I. (2012). Adsorption and leaching potential of imidacloprid pesticide through alluvial soil. Am. J. Anal. Chem. 3, 604-611. doi: 10.4236/ajac.2012.38079

Beketov, M. A., Kefford, B. J., Schäfer, R. B., and Liess, M. (2013). Pesticides reduce regional biodiversity of stream invertebrates. Proc. Natl. Acad. Sci. U.S.A. 110, 11039-11043. doi: 10.1073/pnas.1305618110

Beketov, M. A., and Liess, M. (2008a). Acute and delayed effects of the neonicotinoid insecticide thiacloprid on seven freshwater arthropods. Environ. Toxicol. Chem. 27, 461-470. doi: 10.1897/07-322R.1

Beketov, M. A., and Liess, M. (2008b). Potential of 11 pesticides to initiate downstream drift of stream macroinvertebrates. Arch. Environ. Contam. Toxicol. 55, 247-253. doi: 10.1007/s00244-007-9104-3

Beketov, M. A., and Liess, M. (2008c). Variability of pesticide exposure in a stream mesocosm system: macrophyte-dominated vs. non-vegetated sections. Environ. Pollut. 156, 1364-1367. doi: 10.1016/j.envpol.2008.08.014

Beketov, M., Schäfer, R. B., Marwitz, A., Paschke, A., and Liess, M. (2008). Long-term stream invertebrate community alterations induced by the insecticide thiacloprid: effect concentrations and recovery dynamics. Sci. Total Environ. 405, 96-108. doi: 10.1016/j.scitotenv.2008. 07.001

Bonmatin, J. M., Giorio, C., Girolami, V., Goulson, D., Kreutzweiser, D. P., Krupke, C., et al. (2015). Environmental fate and exposure; neonicotinoids and fipronil. Environ. Sci. Pollut. Res. 22, 35-67. doi: 10.1007/s11356-014-3332-7

Böttger, R., Feibicke, M., Schaller, J., and Dudel, G. (2013). Effects of lowdosed imidacloprid pulses on the functional role of the caged amphipod Gammarus roeseli in stream mesocosms. Ecotoxicol. Environ. Saf. 93, 93-100. doi: 10.1016/j.ecoenv.2013.04.006

Brock, T. C. M., Belgers, J. D. M., Roessink, I., Cuppen, J. G. M., and Maund, S. J. (2010). Macroinvertebrate responses to insecticide application between sprayed and adjacent nonsprayed ditch sections of different sizes. Environ. Toxicol. Chem. 29, 1994-2008. doi: 10.1002/etc.238

Brown, A. W. A. (1978). Ecology of Pesticides. New York, NY: John Wiley \& Sons, Inc.

Cameron, S. A., Lozier, J. D., Strange, J. P., Koch, J. B., Cordes, N., Solter, L. F., et al. (2011). Patterns of widespread decline in North American bumble bees. Proc. Natl. Acad. Sci. U.S.A. 108, 662-667. doi: 10.1073/pnas.1014743108

Cataño, H. C., Carranza, E., Huamaní, C., and Hernández, A. F. (2008). Plasma cholinesterase levels and health symptoms in Peruvian farm workers exposed to organophosphate pesticides. Arch. Environ. Contam. Toxicol. 55, 153-159. doi: 10.1007/s00244-007-9095-0

CCME (2007). Canadian Water Quality Guidelines: Imidacloprid. Scientific Supporting Document. Winnipeg: Canadian Council of Ministers of the Environment.

Cleveland, C. B., Mayes, M. A., and Cryer, S. A. (2002). An ecological risk assessment for spinosad use on cotton. Pest Manage. Sci. 58, 70-84. doi: $10.1002 /$ ps.424

Colombo, V., Mohr, S., Berghahn, R., and Pettigrove, V. J. (2013). Structural changes in a macrozoobenthos assemblage after imidacloprid pulses in aquatic field-based microcosms. Arch. Environ. Contam. Toxicol. 65, 683-692. doi: 10.1007/s00244-013-9940-2

Daam, M. A., Santos Pereira, A. C., Silva, E., Caetano, L., and Cerejeira, M. J. (2013). Preliminary aquatic risk assessment of imidacloprid after application in an experimental rice plot. Ecotoxicol. Environ. Saf. 97, 78-85. doi: 10.1016/j.ecoenv.2013.07.011

Denning, A., Ernst, W. R., Julien, G. R., Doe, K. G., Cook, A., Bernier, M., et al. (2004). An Assessment of Buffer Zone Effectiveness in Reducing
Pesticide Runoff from Potato Fields in Prince Edward Island (20012002). Atlantic Region: Environment Canada, Environmental Protection Branch.

Ding, Z., Yang, Y., Jin, H., Yu, H., Feng, J., Zhang, X., et al. (2004). Acute toxicity and bioconcentration factor of three pesticides on Brachydanio rerio. Ying Yong Sheng Tai Xue Bao 15, 888-890.

Douglas, M., and Tooker, J. F. (2015). Large-scale deployment of seed treatments has driven rapid increase in use of neonicotinoid insecticides and preemptive pest management in U.S. field crops. Environ. Sci. Technol. 49, 5088-5097. doi: $10.1021 /$ es506141g

Druckrey, H., and Küpfmüller, K. (1949). Dosis und Wirkung - Beiträge zur theoretischen Pharmakologie. Freiburg im Breisgau: Cantor GmbH.

EFSA (2013). Conclusion on the peer review of the pesticide risk assessment for bees for the active substance imidacloprid. EFSA J. 11:3068. doi: 10.2903/j.efsa.2013.3068

Elbert, A., Haas, M., Springer, B., Thielert, W., and Nauen, R. (2008). Applied aspects of neonicotinoid uses in crop protection. Pest Manag. Sci. 64, 1099-1105. doi: 10.1002/ps.1616

Englert, D., Bundschuh, M., and Schulz, R. (2012). Thiacloprid affects trophic interaction between gammarids and mayflies. Environ. Pollut. 167, 41-46. doi: 10.1016/j.envpol.2012.03.024

Escher, B. I., Ashauer, R., Dyer, S., Hermens, J. L. M., Lee, J.-H., Leslie, H. A., et al. (2011). Crucial role of mechanisms and modes of toxic action for understanding tissue residue toxicity and internal effect concentrations of organic chemicals. Integr. Environ. Assess. Manag. 7, 28-49. doi: 10.1002/ ieam. 100

European Commission (2013). Commission Implementing Regulation (EU) No 485/2013. Brussels: Official Journal of the European Union.

Fitzpatrick, Ú., Murray, T. E., Paxton, R. J., Breen, J., Cotton, D., Santorum, V., et al. (2007). Rarity and decline in bumblebees - a test of causes and correlates in the Irish fauna. Biol. Conserv. 136, 185-194. doi: 10.1016/j.biocon.2006.11.012

Forister, M. L., Cousens, B., Harrison, J. G., Anderson, K., Thorne, J. H., Waetjen, D., et al. (2016). Increasing neonicotinoid use and the declining butterfly fauna of lowland California. Biol. Lett. 12:20160475. doi: 10.1098/rsbl.2016.0475

Fox, P. J., and Matthiessen, P. (1982). Acute toxicity to fish of low-dose aerosol applications of endosulfan to control tsetse fly in the Okavango delta, Botswana. Environ. Polluti. Ser. A 27, 129-142. doi: 10.1016/0143-1471(82)90105-2

Furlan, L., and Kreutzweiser, D. (2015). Alternatives to neonicotinoid insecticides for pest control: case studies in agriculture and forestry. Environ. Sci. Pollut. Res. 22, 135-147. doi: 10.1007/s11356-014-3628-7

Garric, A., and Hir, P. L. (2016). Loi sur la biodiversité: la France bannit les pesticides tueurs d'abeilles. Le Monde.

Gilburn, A. S., Bunnefeld, N., Wilson, J. M., Botham, M. S., Brereton, T. M., Fox, R., et al. (2015). Are neonicotinoid insecticides driving declines of widespread butterflies? PeerJ 3:e1402. doi: 10.7717/peerj.1402

González-Pradas, E., Ureía-Amate, M. D., Flores-Céspedes, F., Fernández-Pérez, M., Garratt, J., and Wilkins, R. (2002). Leaching of imidacloprid and procymidone in a greenhouse of southeast of Spain. Soil Sci. Soc. Am. J. 66, 1821-1828. doi: 10.2136/sssaj2002.1821

Goulson, D. (2013). An overview of the environmental risks posed by neonicotinoid insecticides. J. Appl. Ecol. 50, 977-987. doi: 10.1111/13652664.12111

Hallmann, C. A., Foppen, R. P. B., van Turnhout, C. A. M., de Kroon, H., and Jongejans, E. (2014). Declines in insectivorous birds are associated with high neonicotinoid concentrations. Nature 511, 341-343. doi: 10.1038/nature13531

Hayasaka, D., Korenaga, T., Sánchez-Bayo, F., and Goka, K. (2012a). Differences in ecological impacts of systemic insecticides with different physicochemical properties on biocenosis of experimental paddy fields. Ecotoxicology 21, 191-201. doi: 10.1007/s10646-011-0778-y

Hayasaka, D., Korenaga, T., Suzuki, K., Saito, F., Sánchez-Bayo, F., and Goka, K. (2012b). Cumulative ecological impacts of two successive annual treatments of imidacloprid and fipronil on aquatic communities of paddy mesocosms. Ecotoxicol. Environ. Saf. 80, 355-362. doi: 10.1016/j.ecoenv.2012.04.004

Hayasaka, D., Suzuki, K., Nomura, T., Nishiyama, M., Nagai, T., Sánchez-Bayo, F., et al. (2013). Comparison of acute toxicity of two neonicotinoid insecticides, imidacloprid and clothianidin, to five cladoceran species. J. Pestic. Sci. 38, 44-47. doi: 10.1584/jpestics.D12-061 
Hladik, M. L., and Calhoun, D. L. (2012). Analysis of the Herbicide Diuron, Three Diuron Degradates, and Six Neonicotinoid Insecticides in Water-Method Details and Application to Two Georgia streams. Reston, VA: U.S. Geological Survey.

Hladik, M. L., Kolpin, D. W., and Kuivila, K. M. (2014). Widespread occurrence of neonicotinoid insecticides in streams in a high corn and soybean producing region, USA. Environ. Pollut. 193, 189-196. doi: 10.1016/j.envpol.2014.06.033

Jeschke, P., and Nauen, R. (2008). Neonicotinoids-from zero to hero in insecticide chemistry. Pest Manag. Sci. 64, 1084-1098. doi: 10.1002/ps.1631

Jeschke, P., Nauen, R., Schindler, M., and Elbert, A. (2011). Overview of the status and global strategy for neonicotinoids. J. Agric. Food Chem. 59, 2897-2908. doi: $10.1021 /$ jf101303g

Jinguji, H., Thuyet, D., Ueda, T., and Watanabe, H. (2013). Effect of imidacloprid and fipronil pesticide application on Sympetrum infuscatum (Libellulidae: Odonata) larvae and adults. Paddy Water Environ. 11, 277-284. doi: 10.1007/s10333-012-0317-3

Johnson, J. D., and Pettis, J. S. (2014). A survey of imidacloprid levels in water sources potentially frequented by honeybees (Apis mellifera) in the Eastern USA. Water Air Soil Pollut. 225, 1-6. doi: 10.1007/s11270-014-2127-2

Jones, A., Harrington, P., and Turnbull, G. (2014). Neonicotinoid concentrations in arable soils after seed treatment applications in preceding years. Pest Manag. Sci. 70, 1780-1784. doi: 10.1002/ps.3836

Kattwinkel, M., Reichert, P., Rüegg, J., Liess, M., and Schuwirth, N. (2016). Modeling macroinvertebrate community dynamics in stream mesocosms contaminated with a pesticide. Environ. Sci. Technol. 50, 3165-3173. doi: 10.1021/acs.est.5b04068

Krebs, J. R., Wilson, J. D., Bradbury, R. B., and Siriwardena, G. M. (1999). The second Silent Spring? Nature 400, 611-612. doi: 10.1038/23127

Kreuger, J., Graaf, S., Patring, J., and Adielsson, S. (2010). Pesticides in Surface Water in Areas with Open Ground and Greenhouse Horticultural Crops in Sweden 2008. Uppsala: Swedish University of Agricultural Sciences.

Kreutzweiser, D., Good, K., Chartrand, D., Scarr, T., and Thompson, D. (2007). Non-target effects on aquatic decomposer organisms of imidacloprid as a systemic insecticide to control emerald ash borer in riparian trees. Ecotoxicol. Environ. Saf. 68, 315-325. doi: 10.1016/j.ecoenv.2007.04.011

Kreutzweiser, D. P., Good, K. P., Chartrand, D. T., Scarr, T. A., Holmes, S. B., and Thompson, D. G. (2008a). Effects on litter-dwelling earthworms and microbial decomposition of soil-applied imidacloprid for control of wood-boring insects. Pest Manag. Sci. 64, 112-118. doi: 10.1002/ps.1478

Kreutzweiser, D. P., Good, K. P., Chartrand, D. T., Scarr, T. A., and Thompson, D. G. (2008b). Toxicity of the systemic insecticide, imidacloprid, to forest stream insects and microbial communities. Bull. Environ. Contam. Toxicol. 80, 211-214. doi: 10.1007/s00128-007-9347-8

Kunce, W., Josefsson, S., Örberg, J., and Johansson, F. (2015). Combination effects of pyrethroids and neonicotinoids on development and survival of Chironomus riparius. Ecotoxicol. Environ. Saf. 122, 426-431. doi: 10.1016/j.ecoenv.2015.09.008

Kurwadkar, S., Wheat, R., McGahan, D. G., and Mitchell, F. (2014). Evaluation of leaching potential of three systemic neonicotinoid insecticides in vineyard soil. J. Contam. Hydrol. 170, 86-94. doi: 10.1016/j.jconhyd.2014.09.009

Kwok, Y. C., Hsieh, D. P. H., and Wong, P. K. (2005). Toxicity identification evaluation (TIE) of pore water of contaminated marine sediments collected from Hong Kong waters. Mar. Pollut. Bull. 51, 1085-1091. doi: 10.1016/j.marpolbul.2005.06.009

Lahr, J., Diallo, A. O., Gadji, B., Diouf, P. S., Bedeaux, J. J. M., Badji, A., et al. (2000). Ecological effects of experimental insecticide applications on invertebrates in Sahelian temporary ponds. Environ. Toxicol. Chem. 19, 1278-1289. doi: $10.1002 /$ etc. 5620190509

Liess, M., Foit, K., Becker, A., Hassold, E., Dolciotti, I., Kattwinkel, M., et al. (2013). Culmination of low-dose pesticide effects. Environ. Sci. Technol. 47, 8862-8868. doi: $10.1021 / \mathrm{es} 401346 \mathrm{~d}$

Liu, X., Xu, X., Li, C., Zhang, H., Fu, Q., Shao, X., et al. (2015). Degradation of chiral neonicotinoid insecticide cycloxaprid in flooded and anoxic soil. Chemosphere 119, 334-341. doi: 10.1016/j.chemosphere.2014.06.016

Macfadyen, S., Hardie, D. C., Fagan, L., Stefanova, K., Perry, K. D., DeGraaf, H. E., et al. (2014). Reducing insecticide use in broad-acre grains production: an Australian study. PLoS ONE 9:e89119. doi: 10.1371/journal.pone. 0089119
Malato, S., Caceres, J., Agüera, A., Mezcua, M., Hernando, D., Vial, J., et al. (2001). Degradation of imidacloprid in water by photo-Fenton and $\mathrm{TiO}_{2}$ photocatalysis at a solar pilot plant: a comparative study. Environ. Sci. Technol. 35, 4359-4366. doi: $10.1021 / \mathrm{es} 000289 \mathrm{k}$

Mason, R., Tennekes, H., Sánchez-Bayo, F., and Jepsen, P. U. (2013). Immune suppression by neonicotinoid insecticides at the root of global wildlife declines. J. Environ. Immunol. Toxicol. 1, 3-12. doi: 10.7178/jeit.1

Matsumura, F. (1985). Toxicology of Pesticides. New York, NY: Plenum Press.

Matthiessen, P., Fox, P. J., Douthwaite, R. J., and Wood, A. B. (1982). Accumulation of endosulfan residues in fish and their predators after aerial spraying for the control of tsetse fly in Botswana. Pestic. Sci. 13, 39-48. doi: $10.1002 /$ ps.2780130107

Maund, S. J., Sherratt, T. N., Stickland, T., Biggs, J., Williams, P., Shillabeer, N., et al. (1997). Ecological considerations in pesticide risk assessment for aquatic ecosystems. Pestic. Sci. 49, 185-190.

Medina, M., Barata, C., Telfer, T., and Baird, D. J. (2004). Effects of cypermethrin on marine plankton communities: a simulated field study using mesocosms. Ecotoxicol. Environ. Saf. 58, 236-245. doi: 10.1016/j.ecoenv.2003.07.001

Miranda, G. R. B., Raetano, C. G., Silva, E., Daam, M. A., and Cerejeira, M. J. (2011). Environmental fate of neonicotinoids and classification of their potential risks to hypogean, epygean, and surface water ecosystems in Brazil. Hum. Ecol. Risk Assess. 17, 981-995. doi: 10.1080/10807039.2011.588159

Morrissey, C. A., Mineau, P., Devries, J. H., Sánchez-Bayo, F., Liess, M., Cavallaro, M. C., et al. (2015). Neonicotinoid contamination of global surface waters and associated risk to aquatic invertebrates: a review. Environ. Int. 74, 291-303. doi: 10.1016/j.envint.2014.10.024

Morse, J. C., Stark, B. P., and McCafferty, P. W. (1993). Southern Appalachian streams at risk: implications for mayflies, stoneflies, caddisflies, and other aquatic biota. Aquat. Conserv. Mar. Freshw. Ecosyst. 3, 293-303. doi: 10.1002/aqc.3270030404

Motobayashi, T., Genka, M., Khanh Phong, T., and Watanabe, H. (2012). Effects of formulation and treatment method of imidacloprid in nursery boxes on aquatic insects inhabiting rice paddy fields. Jpn. J. Appl. Entomol. Zool. 56, 169-172. doi: 10.1303/jjaez.2012.169

Phong, T. K., Nhung, D. T. T., Motobayashi, T., Thuyet, D. Q., and Watanabe, H. (2009). Fate and transport of nursery-box-applied tricyclazole and imidacloprid in paddy fields. Water Air Soil Pollut. 202, 3-12. doi: 10.1007/s11270-0089953-z

Nyman, A.-M., Hintermeister, A., Schirmer, K., and Ashauer, R. (2013). The insecticide imidacloprid causes mortality of the freshwater amphipod Gammarus pulex by interfering with feeding behavior. PLOS ONE 8:e62472. doi: 10.1371/journal.pone.0062472

Osborne, J. L. (2012). Ecology: bumblebees and pesticides. Nature 491, 43-45. doi 10.1038 /nature11637

Parsons, J. T., and Surgeoner, G. A. (1991). Effect of exposure time on the acute toxicities of permethrin, fenitrothion, carbaryl and carbofuran to mosquito larvae. Environ. Toxicol. Chem. 10, 1219-1227. doi: 10.1002/etc.5620100913

Pestana, J. L. T., Alexander, A. C., Culp, J. M., Baird, D. J., Cessna, A. J., and Soares, A. M. V. M. (2009). Structural and functional responses of benthic invertebrates to imidacloprid in outdoor stream mesocosms. Environ. Pollut. 157, 2328-2334. doi: 10.1016/j.envpol.2009.03.027

Peveling, R., McWilliam, A. N., Nagel, P., Rasolomanana, H., Raholijaona, Rakotomianina, L., et al. (2003). Impact of locust control on harvester termites and endemic vertebrate predators in Madagascar. J. Appl. Ecol. 40, 729-741. doi: 10.1046/j.1365-2664.2003.00833.x

Phillips, P. J., and Bode, R. W. (2004). Pesticides in surface water runoff in south-eastern New York State, USA: seasonal and stormflow effects on concentrations. Pest Manag. Sci. 60, 531-543. doi: 10.1002/ps.879

Potts, G. R. (1986). The Partridge - Pesticides, Predation and Conservation. London: Collins.

Roessink, I., Merga, L. B., Zweers, H. J., and van den Brink, P. J. (2013). The neonicotinoid imidacloprid shows high chronic toxicity to mayfly nymphs. Environ. Toxicol. Chem. 32, 1096-1100. doi: 10.1002/etc.2201

Rondeau, G., Sánchez-Bayo, F., Tennekes, H. A., Decourtye, A., RamírezRomero, R., and Desneux, N. (2014). Delayed and time-cumulative toxicity of imidacloprid in bees, ants and termites. Sci. Rep. 4:5566. doi: 10.1038/srep05566

Sánchez-Bayo, F. (1991). "Temporal diversity and structure within a bird community," in Diversidad Biologica/Biological Diversity, eds F. D. Pineda, M. 
A. Casado, J. M. D. Miguel, and J. Montalvo (Madrid: Centro de Estudios Ramon Areces S.A.), 155-159.

Sánchez-Bayo, F. (2009). From simple toxicological models to prediction of toxic effects in time. Ecotoxicology 18, 343-354. doi: 10.1007/s10646-008-0290-1

Sánchez-Bayo, F. (2011). "Impacts of agricultural pesticides on terrestrial ecosystems," in Ecological Impacts of Toxic Chemicals, eds F. Sánchez-Bayo, P. J. van den Brink, and R. Mann (Beijing: Bentham Science Publishers), 63-87. Available online at: http://www.benthamdirect.com/51436/volume/1

Sánchez-Bayo, F. (2014). The trouble with neonicotinoids. Science 346, 806-807. doi: 10.1126/science.1259159

Sánchez-Bayo, F., Ahmad, R., and Goka, K. (2007). "Evaluation of the standard quotient and EcoRR methodologies based on field monitoring from rice fields," in Rational Environmental Management of Agrochemicals, eds I. R. Kennedy, K. R. Solomon, S. J. Gee, A. N. Crossan, S. Wang, and F. Sánchez-Bayo (Washington, DC: American Chemical Society), 66-86.

Sánchez-Bayo, F., and Goka, K. (2005). Unexpected effects of zinc pyrithione and imidacloprid on Japanese medaka fish (Oryzias latipes). Aquat. Toxicol. 74, 285-293. doi: 10.1016/j.aquatox.2005.06.003

Sánchez-Bayo, F., and Goka, K. (2006a). Ecological effects of the insecticide imidacloprid and a pollutant from antidandruff shampoo in experimental rice fields. Environ. Toxicol. Chem. 25, 1677-1687. doi: 10.1897/05-404R.1

Sánchez-Bayo, F., and Goka, K. (2006b). Influence of light in acute toxicity bioassays of imidacloprid and zinc pyrithione to zooplankton crustaceans Aquat. Toxicol. 78, 262-271. doi: 10.1016/j.aquatox.2006.03.009

Sánchez-Bayo, F., and Hyne, R. V. (2014). Detection and analysis of neonicotinoids in river waters - development of a passive sampler for three commonly used insecticides. Chemosphere 99, 143-151. doi: 10.1016/j.chemosphere.2013.10.051

Schaafsma, A., Limay-Rios, V., Baute, T., Smith, J., and Xue, Y. (2015). Neonicotinoid insecticide residues in surface water and soil associated with commercial maize (corn) fields in southwestern Ontario. PLoS ONE 10:e0118139. doi: 10.1371/journal.pone.0118139

Schaafsma, A., Limay-Rios, V., Xue, Y., Smith, J., and Baute, T. (2016). Fieldscale examination of neonicotinoid insecticide persistence in soil as a result of seed treatment use in commercial maize (corn) fields in southwestern Ontario. Environ. Toxicol. Chem. 35, 295-302. doi: 10.1002/etc.3231

Seagraves, M. P., and Lundgren, J. G. (2012). Effects of neonicitinoid seed treatments on soybean aphid and its natural enemies. J. Pest Sci. 85, 125-132. doi: 10.1007/s10340-011-0374-1

Siebers, J., Binner, R., and Wittich, K.-P. (2003). Investigation on downwind short-range transport of pesticides after application in agricultural crops. Chemosphere 51, 397-407. doi: 10.1016/S0045-6535(02)00820-2

Simon-Delso, N., Amaral-Rogers, V., Belzunces, L. P., Bonmatin, J. M., Chagnon, M., Downs, C., et al. (2015). Systemic insecticides (neonicotinoids and fipronil): trends, uses, mode of action and metabolites. Environ. Sci. Pollut. Res. 22, 5-34. doi: $10.1007 / \mathrm{s} 11356-014-3470-\mathrm{y}$

Smit, C. E., Posthuma-Doodeman, C. J. A. M., van Vlaardingen, P. L. A., and de Jong, F. M. W. (2015). Ecotoxicity of imidacloprid to aquatic organisms: derivation of water quality standards for peak and long-term exposure. Hum. Ecol. Risk Assess. 21, 1608-1630. doi: 10.1080/10807039.2014.964071

Song, M. Y., Stark, J. D., and Brown, J. J. (1997). Comparative toxicity of four insecticides, including imidacloprid and tebufenozide, to four aquatic arthropods. Environ. Toxicol. Chem. 16, 2494-2500. doi: 10.1002/etc.56201 61209

Sorg, M., Schwan, H., Stenmans, W., and MüLler, A. (2013). Ermittlung der Biomassen flugaktiver Insekten im Naturschutzgebiet Orbroicher Bruch mit Malaise Fallen in den Jahren 1989 und 2013. Proc. Krefeld Entomol. Soc. 1, 1-5.

Sorrell, B. K., and Boon, P. I. (1992). Biogeochemistry of billabong sediments. II Seasonal variations in methane production. Freshw. Biol. 27, 435-445. doi: 10.1111/j.1365-2427.1992.tb00552.x

Starner, K., and Goh, K. (2012). Detections of the neonicotinoid insecticide imidacloprid in surface waters of three agricultural regions of California, USA, 2010-2011. Bull. Environ. Contam. Toxicol. 88, 316-321. doi: 10.1007/s00128011-0515-5

Stoughton, S. J., Liber, K., Culp, J., and Cessna, A. (2008). Acute and chronic toxicity of imidacloprid to the aquatic invertebrates Chironomus tentans and Hyalella azteca under constant- and pulse-exposure conditions. Arch. Environ. Contam. Toxicol. 54, 662-673. doi: 10.1007/s00244-007-9073-6
Sur, R., and Stork, A. (2003). Uptake, translocation and metabolism of imidacloprid in plants. Bull. Insectol. 56, 35-40.

Suter, G. W. II, and Cormier, S. M. (2015). Why care about aquatic insects: uses, benefits, and services. Integr. Environ. Assess. Manag. 11, 188-194. doi: 10.1002/ ieam. 1600

Tennekes, H. A. (2010a). The significance of the Druckrey-Küpfmüller equation for risk assessment - the toxicity of neonicotinoid insecticides to arthropods is reinforced by exposure time. Toxicology 276, 1-4. doi: 10.1016/j.tox.2010.07.005

Tennekes, H. A. (2010b). The Systemic Insecticides: A Disaster in the Making. Zutphen: ETS Nederland BV.

Tennekes, H. A., and Sánchez-Bayo, F. (2013). The molecular basis of simple relationships between exposure concentration and toxic effects with time. Toxicology 309, 39-51. doi: 10.1016/j.tox.2013. 04.007

Thuyet, D. Q., Jorgenson, B. C., Wissel-Tyson, C., Watanabe, H., and Young, T. M. (2012). Wash off of imidacloprid and fipronil from turf and concrete surfaces using simulated rainfall. Sci. Total Environ. 414, 515-524. doi: 10.1016/j.scitotenv.2011.10.051

Thuyet, D. Q., Watanabe, H., Yamazaki, K., and Takagi, K. (2011). Photodegradation of imidacloprid and fipronil in rice-paddy water. Bull. Environ. Contam. Toxicol. 86, 548-553. doi: 10.1007/s00128-01 $1-0243-\mathrm{x}$

Tomizawa, M., and Casida, J. (2005). Neonicotinoid insecticide toxicology: mechanisms of selective action. Annu. Rev. Pharmacol. Toxicol. 45, 247-268. doi: 10.1146/annurev.pharmtox.45.120403.095930

Tomlin, C. D. S. (ed.). (2009). The e-Pesticide Manual, 12th Edn. Surrey: British Crop Protection Council.

Uğurlu, P., Ünlü, E., and Satar, E. I. (2015). The toxicological effects of thiamethoxam on Gammarus kischineffensis (Schellenberg 1937) (Crustacea: Amphipoda). Environ. Toxicol. Pharmacol. 39, 720-726. doi: 10.1016/j.etap.2015.01.013

USGS (2002). Concentrations of Pesticides and Pesticide Degradates in the Croton River Water-Shed in Southeastern New York, July-September 2000. New York, NY: United States Geological Survey.

van den Brink, P. J., Smeden, J. M. V., Bekele, R. S., Dierick, W., De Gelder, D. D. Noteboom, M., et al. (2016). Acute and chronic toxicity of neonicotinoids to nymphs of a mayfly species and some notes on seasonal differences. Environ. Toxicol. Chem. 35, 128-133. doi: 10.1002/etc.3152

van den Brink, P. J., Wijngaarden, R. P. A. V., Lucassen, W. G. H., Brock, T. C. M., and Leeuwangh, P. (1996). Effects of the insecticide Dursban 4E (active ingredient chlorpyrifos) in outdoor experimental ditches: II. Invertebrate community responses and recovery. Environ. Toxicol. Chem. 15, 1143-1153.

van der Sluijs, J. P., Amaral-Rogers, V., Belzunces, L. P., Lexmond, M. F. I. J. B. V., Bonmatin, J.-M., Chagnon, M., et al. (2015). Conclusions of the Worldwide Integrated Assessment on the risks of neonicotinoids and fipronil to biodiversity and ecosystem functioning. Environ. Sci. Pollut. Res. 22, 148-154. doi: $10.1007 / s 11356-014-3229-5$

van der Sluijs, J. P., Simon-Delso, N., Goulson, D., Maxim, L., Bonmatin, J.-M., and Belzunces, L. P. (2013). Neonicotinoids, bee disorders and the sustainability of pollinator services. Curr. Opin. Environ. Sustain. 5, 293-305. doi: 10.1016/j.cosust.2013.05.007

van Dijk, T. C., van Staalduinen, M. A., and van der Sluijs, J. P. (2013). Macroinvertebrate decline in surface water polluted with imidacloprid. PLOS ONE 8:e62374. doi: 10.1371/journal.pone.0062374

Vehovszky, Á., Farkas, A., Ács, A., Stoliar, O., Székács, A., Mörtl, M., et al. (2015). Neonicotinoid insecticides inhibit cholinergic neurotransmission in a molluscan (Lymnaea stagnalis) nervous system. Aquat. Toxicol. 167, 172-179. doi: 10.1016/j.aquatox.2015.08.009

Vijver, M. G., and van den Brink, P. J. (2014). Macro-invertebrate decline in surface water polluted with imidacloprid: a rebuttal and some new analyses. PLoS ONE 9:e89837. doi: 10.1371/journal.pone.0089837

von der Ohe, P. C., Prüss, A., Schäfer, R. B., Liess, M., de Deckere, E., and Brack, W. (2007). Water quality indices across Europe - a comparison of the good ecological status of five river basins. J. Environ. Monit. 9, 970-978. doi: $10.1039 /$ b704699p

Weston, D. P., Chen, D., and Lydy, M. J. (2015). Stormwater-related transport of the insecticides bifenthrin, fipronil, imidacloprid, and chlorpyrifos into a tidal 
wetland, San Francisco Bay, California. Sci. Total Environ. 527-528, 18-25. doi: 10.1016/j.scitotenv.2015.04.095

Woodcock, B. A., Isaac, N. J. B., Bullock, J. M., Roy, D. B., Garthwaite, D. G., Crowe, A., et al. (2016). Impacts of neonicotinoid use on long-term population changes in wild bees in England. Nat. Commun. 7:12459. doi: 10.1038/ncomms 12459

Yamamoto, A., Terao, T., Hisatomi, H., Kawasaki, H., and Arakawa, R. (2012). Evaluation of river pollution of neonicotinoids in Osaka City (Japan) by LC/MS with dopant-assisted photoionisation. J. Environ. Monit. 14, 2189-2194. doi: 10.1039/c2em30296a
Conflict of Interest Statement: The authors declare that the research was conducted in the absence of any commercial or financial relationships that could be construed as a potential conflict of interest.

Copyright $\odot 2016$ Sánchez-Bayo, Goka and Hayasaka. This is an open-access article distributed under the terms of the Creative Commons Attribution License (CC BY). The use, distribution or reproduction in other forums is permitted, provided the original author(s) or licensor are credited and that the original publication in this journal is cited, in accordance with accepted academic practice. No use, distribution or reproduction is permitted which does not comply with these terms. 